\title{
Evaluation of Democracy Education Implementation in Public Education in Central Schools in Surakarta
}

\author{
Yusuf, Sri Yutmini, Sutarno Joyo Hadikusumo, Asrowi
}

\begin{abstract}
This paper aims to evaluate: Evaluation of the implementation of democratic education in the learning of Pancasila and Citizenship Education in Surakarta City Senior High School. Research method with a qualitative approach with observation, documentation and interviews. Data analysis techniques by collecting data, reducing data and drawing conclusions. Test the validity with the triangulation method. Students are trained to be open and dare to express their opinions, respect the opinions of students, can improve the quality of communication interactions between fellow students, teachers, schools and students with their communities. 2) The results of the study evaluated the implementation of democratic education in the subjects of Pancasila Education and Citizenship Education in Surakarta City Senior High School. Students are not seen as objects, but students have been viewed as subjects in the learning process. The results of the study, can be applied in the learning process of democratic education on Pancasila and Citizenship Education subjects compiled in the RPP compiled by the Surakarta City Pancasila and Citizenship Education subject teacher. The implementation is in the learning process, adapted to the conditions of each high school in Surakarta City. The involvement of the school environment and the community environment to support learning also depends on the school environment and the community environment of the students. The novelty in this research is that the school began to involve the school environment and the community environment in learning democracy education. However, not all schools are able to involve the school environment and the community environment to organize democratic education.
\end{abstract}

Index Terms Keywords: Evaluation; Democracy Education; Central Schools

\section{INTRODUCTION}

The day after the proclamation of independence of the Republic of Indonesia, the Preparatory Committee for Indonesian Independence, ratified the 1945 Constitution, in which one of its opening sections emphasized: "Then than that to form an Indonesian state government that protects the entire Indonesian nation and the entire bloodshed of Indonesia and to promote prosperity general, educating the life of the nation, and participating in carrying out world order based on independence, eternal peace and social justice, then the Indonesian independence was formulated in an Indonesian Constitution which was formed in a state structure of the Republic of Indonesia based on the people's sovereignty : The One Godhead, just and civilized humanity, Indonesian unity, and popularism led by wisdom in deliberation / representation, and by realizing a social justice for all the people of Indonesia. "

Revised Manuscript Received on September 22, 2019

Yusuf, Student at Doctoral Program in University of SebelasMaret, and Lecture in University of Slamet Riyadi, Surakarta, Indonesia

Sri Yutmini, Lecture Doctoral Program in University of SebelasMaret, Surakarta, Indonesia

Sutarno Joyo Hadikusumo, Lecture Doctoral Program in University of SebelasMaret, Surakarta, Indonesia

Asrowi, Lecture Doctoral Program in University of SebelasMaret, Surakarta, Indonesia
Thus the Indonesian State formed was a democratic country. Sovereignty in the hands of the people, which is realized by general elections to elect a direct President and vice president, election of members of the Regional Representatives Council, Election of members of DPR and DPRD level I and II carried out for all Indonesian citizens who have rights and fulfill the provisions of the Law both in Indonesia and abroad. However, the reality is that the implementation of elections in Indonesia still has many problems in its implementation. There are still Indonesian citizens who have not yet been registered as voters. There is money politics, black campaigns, involvement of the State civil apparatus, Indonesian Armed Forces, Police to support certain candidate pairs, even though the State Civil Service, Indonesian National Army and the Police must be neutral.

The concepts of three main e-democracy developments and control framework of COBIT 4.1 are employed for constructing our sustainable e-democracy development, which consists of four external components. Such components are development environment, stakeholder and policy, Information and Communication Technology (ICT), and development methodology. The underlying e-democracy applications are introduced based on democratic principles and the OECD framework of citizens| participation. Furthermore, the quality of an e-democracy system is established by using the Technology Acceptance Model (TAM) and the e-government Web Quality Assessment Model (e-government WebQAM). This sustainable development and quality of an e-democracy system can be used as guidelines for successful e-democracy development. (SureeFunilkul, Wichian, 2009)

In fact, the quality of democracy in Indonesia is still low, such as the low level of the legislative population, the commotion of members of the House of Representatives in the trial, such as events that do not reflect the values of democracy. The chaos at the DPR RI plenary meeting that was first held on the instrument for ratification of the board's completeness that occurred in October 2004 was an example. People's representatives in the DPR as a channel for rqakyat aspirations actually act anarchically by hitting and turning tables. The walk out action from some DPR members who felt their speech rights were ignored. This incident is an example of labor for the younger generation towards the implementation of democracy in Indonesia.

\section{LITERATURE REVIEW}

Good democracy is very necessary in the life of society, nation and state. The influence of education and human resources with cognitive, affective and psychomotor abilities towards the values of democracy. These influences cause tolerance, good political awareness, rationality, and participation from every society.

The expected democratic education is education whose democratic values are learned through learning and experiences in democracy. Thus, learning in theory and through the practice of democracy (learning by doing) is very important. Therefore, schooling needs to encourage the growth of ethical behavior and personal responsibility in democracy. That is, in learning democracy, schools need to provide facilities for their students to have freedom of thought, freedom of choice, freedom of action, and freedom to get the results of their actions, which leads to the 
Evaluation of Democracy Education Implementation in Public Education in Central Schools in Surakarta

formation of personal responsibility. The rest, democratic behavior must be conditioned, both in schooling and outside schooling, because it could be that someone else's voice is useful for us, no matter how bad. Without democracy, humans will lose direction. With democracy, everyone will live in a controlled manner.

A democratic country will be realized, if its citizens actively participate in government. To create a democratic country, Pancasila and Citizenship Education has a very important role to foster political awareness for every citizen. The democratic life of the nation must begin to be applied at an early age, during the period of primary education. If citizens understanding of democratic life has been developed at an early age, then the ideals of a democratic Indonesia will be realized.

For this reason, it is necessary to manage democratic education in the learning of Pancasila and Citizenship Education so that the goals of democratic countries can be realized. Teachers as planners, implementers and provide assessments in the learning process play an important role in instilling democratic values through the integration of learning in each subject, especially subjects of Pancasila and Citizen (Trisiana, A: 2016)

Public Senior High School Surakarta, Pancasila and Citizenship Education Teachers are members of the Post-Graduation and Citizenship Education Subject Teachers' Meeting, always able to coordinate in their learning planning. The learning implementation of Pancasila and Citizenship Education in Surakarta State Senior High School in implementing democratic education, teacher of Pancasila and Citizenship Education in each of its learning by providing learning materials, learning strategies and learning methods used starting from learning planning, implementing learning and assessing learning using curriculum 2019.enship Education.

\section{METHODOLOGY}

This research is qualitative research, namely research that can explain and analyze phenomena, events, social activities, attitudes, beliefs, perceptions of a person or group towards something (Hamdi and Bahrudin, 2015: 9). This research is included in interactive qualitative research which is an in-depth study using the technique of collecting data directly from people in their natural environment and interpreting phenomena of how people search for contained meanings and make a comprehensive picture with detailed descriptions of informants (Hamdi and Bahrudin, 2015: 11-12). Data collection techniques in this study are by observation, in-depth interviews and documentation. The data analysis technique uses the interactive analysis model of Miles and Huberman which includes: Data Reduction, Data Display, and Conclusion Drawing. The data validity technique uses data triangulation, source triangulation and method triangulation.

\section{RESULTS AND FINDINGS}

Democracy Education Planning in Learning Pancasila and Citizenship Education in Surakarta State High School.

The planning of democratic education activities in the learning of Pancasila and Citizenship Education at Surakarta Public Senior High School is arranged in the lesson plan (RPP). In the RPP the value of democratic education is designed to be taught to students to practice the values of democracy. Learning planning is a systematic process plan in the learning process about the actions to be taken in the learning process. Systematic means that planning is carried out using certain principles. These principles include decision-making processes, scientific use of knowledge and techniques as well as organized actions or activities (Luddin, 2010: 56)

Basically the implementation of democratic education in the learning of Pancasila and Citizenship Education at Sekol Surakarta State High School aims to enable students to understand and be able to exercise their rights and obligations as smart, skilled Indonesian citizens with character mandated by Pancasila and the 1945 Constitution. Equip students with basic knowledge and abilities related to the relationship between citizens and the State as well as preliminary education to defend the State to become citizens who can be relied on by the nation and the State. Democracy is a way of thinking, behaving, and acting that values the rights and obligations of himself and others (Anwar and Salam, 2015: 179).

Schools, especially the State Senior High School Surakarta as an educational institution have a major role in fostering a democratic culture among students. Therefore, the educational environment must present a democratic culture in the management of its education. The environment becomes a place where students know, recognize, and implement democratic behavior. In this way, students can respect the rights of others and understand the obligations that must be carried out as mandated by Pancasila and the 1945 Constitution. Winataputra explained that: Citizenship

Education (now Pancasila and Citizenship Education) is a subject that has one of its missions as education value. In the process of national education, Pancasila and Citizenship Education is basically a pedagogical vehicle for the development of character or character. (Lion, 2014: 109).

Similarities, differences and uniqueness of current and past research.

Research Now in democratic education planning activities in the learning of Pancasila and Citizenship Education at Surakarta Public High School, it is designed with a learning implementation plan (RPP) made in the Teacher's Consultation Subjects of Pancasila and Citizenship Education. In the RPP the values of democratic education will be taught to students, so that awareness arises for students to practice the values of democracy. In principle, the implementation of democratic education in the learning of Pancasila and Citizenship Education in Surakarta Public High School aims to enable students to know, understand and be able to exercise their rights and obligations as smart, skilled Indonesian citizens, characterized by the Pancasila and the 1945 Constitution . E-governance or e-government uses the tools of Information Technology to enhance and speedup government/s activities more rationally for the welfare of the people. In this paper an attempt has been made to provide a brief scenario of Indian e-governance/Panchayat (rural government), to identify the gap and requirements for e-government services for rural areas, Information Kiosk for e-governance and to recommend Policy Issues for e-government Services for Rural Areas particularly emphasising the need for Small and Medium Entrepreneurs as alternative for rural economy for sustainable development considering various aspects (BiswatoshSengupta: 2009)

Previous research by Moswela (2010) reveals reciprocal social relations between students and teachers in the classroom. The teacher considers students to be mature enough in making decisions that are responsible for the rules that govern their behavior. Collaborative interactions between teachers and students increase intellectual activity and accommodate learning in the meaning of development. The teacher's actions or acceptance of student participation in class decisions, arises from the wisdom that if they do not choose it, students may not comply with rules and regulations, thus exacerbating behavior problems in the classroom. Bullying is a concern that can frustrate the efforts of teachers to create a democratic classroom environment.

Uniqueness In planning democratic education in the learning of Pancasila and Citizenship Education in Surakarta Public High School, democratic values have been contained in the Learning Implementation Plan (RPP) made, so that teachers easily carry out learning in accordance with the RPP. If there are shortcomings in the implementation of learning, the lesson plan will be corrected at the next meeting.

Implementation of democracy education in learning Pancasila and Citizenship Education in Surakarta State High School

Surakarta State Senior High School provides space for students to express their views on issues and issues of citizenship related to the material being taught. Students are invited to be open, dare to express their opinions and are trained to respect the opinions of other students. The lesson plan (lesson plan) is a plan made by the teacher before teaching. A common mistake teachers make is never making a lesson plan when they are going to teach. The quality of teacher learning that begins with the learning plan will be very different from the teacher who does not make a learning plan (Chatib, 1010: 159-160)

Learning about democratic education is expected to improve interaction between students and between students and teachers. The implementation process is the implementation of a predetermined learning plan, such as realizing goals based on situations and conditions that have been predicted in planning (Sagala, 2009: 60).

The use of variations in learning methods is needed to avoid the boredom of students in the learning process. The use of information and communication technology as a source of learning, can enrich the material delivered to students. The teacher encourages students to be active in the learning process. Students need not be shy in expressing their opinions in the learning process.

The role of schools in fostering a culture of democracy in everyday life is very important, so that democratic education is not only limited to the theory presented, but also provided a place to practice democratic life for all school members. Pancasila and Citizenship Education should be able to equip students with adequate intellectual knowledge and skills, so that it is possible to participate intelligently and responsibly in various dimensions of life that can shape democratic attitudes. With Pancasila and Citizenship education it is expected to form a more democratic culture of citizenship. The European Commission Interactive Policy-Making (IPM) initiative launched in 2001 with respect to its potential to promote democratic participation in the European Union (EU). It is argued that the EU is an example of the consultative, if not participatory model

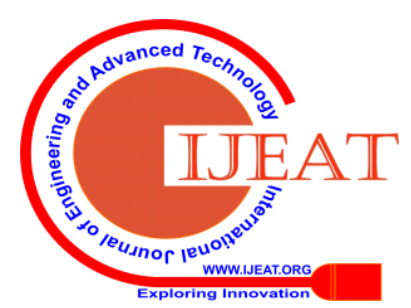


of e-democracy. The first section reviews the existing literature on the implications of Information Communication Technologies (ICTs) for democratic participation, followed by a brief history of e-government and e-democracy in the EU in the second section. The third section investigates the IPM project in detail, before evaluating the findings in the last section (Tuna Baskoy: 2009).

Similarities, differences and uniqueness of current and previous research Research Now, Surakarta 1 State Senior High School provides an opportunity for students to express opinions about issues and issues of citizenship related to the material being taught. Students are invited to be open and dare to express their opinions. Students are trained to respect the opinions of other students. Learning democratic education is expected to increase interaction between students, and between students and teachers. The role of schools in fostering a culture of democracy in everyday life is very important, so that education in democracy is not only limited to theory, but the theory conveyed can be applied by all school members.

Previous research shows that school managers must develop a community that involves teachers, students and parents in various events, and strive for comprehensive protection when developing democratic policies in schools. Equality and social justice must be applied to the individual needs of students and teachers. The research also shows the dilemma facing principals in elementary and junior high schools in Taiwan: failure to communicate through official channels, lack of accountability to take part in authority, constraints on the ability of principals, struggles between participatory, and democracy as obstacles to school effectiveness resulting from problems in policy regulations, school leadership, and shared vision of school stakeholders. (Kao, 2015).

The uniqueness of students is given the opportunity to express opinions, ideas, knowledge related to the learning material that the teacher conveyed. The involvement of students in learning is very emphasized. Students are taught to be able to accept and respect the opinions of friends who are different from their opinions. Learners apply democratic attitudes both in the school environment and their living environment.

3. Evaluation of the implementation of democratic education in the learning of the Surakarta State High School Pancasila and Citizenship Education

Planning for the implementation of the Pancasila and Citizenship Education learning prepared by the teacher by incorporating elements of democratic education, in its implementation is not fully in accordance with the Learning Implementation Plan. Lack of RPP made known when learning takes place. The role of the teacher is to present a variety of learning methods used, the use of information and communication technology to enrich the learning resources to the maximum. The learning process of Pancasila and Citizenship Education which tends to use the lecture method has already been reduced.

Democracy is an attitude and way of thinking that reflects equality showing that in living a democratic society there is only one class of equal citizens who instill a general status for all. The position of equality of citizenship is then by the rights and freedoms required by the principle of equal freedom and the principle of fair equality of opportunity, including the right of all people to have the right to elect and be elected to public office, etc. The teacher's perspective on students has changed. Students are no longer the object of teaching, but students have been seen as subjects of learning. In teacher learning, it is expected to be able to encourage students to develop themselves according to their potential. More teachers function as mentors, advisors, motivators of students when learning takes place. (Supriyadi, 2015: 2)

imilarities, differences and uniqueness of current and pas research. Planning for the implementation of Pancasila and Citizenship Education learning previously prepared by teachers by incorporating elements of democratic education, in its implementation is not fully in accordance with the RPP. Lack of RPP made known when learning takes place. Teacher participation to present a variety of learning methods used when learning takes place, the use of information and communication technology to enrich learning resources is quite maximal. The learning process of Pancasila and Citizenship Education which has tended to use more and more lecture methods has been reduced (Trisiana, A: 2015).

Previous research shows schools are places where democratic ideals such as equality, freedom of justice are instilled in students. Teachers are the main instrument of democratic change to continue to develop, students must be taught to appreciate it as a way of life. The skills needed to build democracy do not develop automatically in students. Teaching democracy means preparing students to become citizens who will preserve and shape democracy in the future. (Subba, 2014)

The uniqueness of Surakarta State High School has changed their perspective towards their students. Students are no longer the object of teaching, but students have been seen as subjects of learning. Students as active actors in the learning process. Teachers are expected to be able to encourage students to develop themselves according to their potential. The teacher functions more as a facilitator, mentor, advisor, student motivator when learning takes place.

The planning of democratic education activities in the learning of Pancasila and Citizenship Education in Surakarta State Senior High School is outlined in the learning implementation plan (RPP). In RPP listed the value of democratic education that will be taught and understood to students, so that awareness arises for students in applying the values of democracy. The implementation of democratic education in the learning of Pancasila and Citizenship Education at Surakarta State High School aims to enable students to understand and carry out their rights and obligations as intelligent, skilled Indonesian citizens, characterized by the Pancasila and the 1945 Constitution.

Schools, especially the Surakarta State High School have a major role in fostering a democratic culture among students. Therefore, the educational environment must present a democratic culture in the management of its education. The environment is also a place for students to recognize, know and implement democratic behavior. Thus students can respect the rights of others and understand their obligations that must be carried out as mandated by Pancasila and the 1945 Constitution.

2. The implementation of democratic education in the learning of Pancasila and Citizenship Education in Surakarta Public High School

Surakarta State High School provides an opportunity for students to express their opinions on issues and issues of citizenship related to the material being taught. Students are invited to be open and dare to express their opinions and are trained to respect the opinions of other students. Learning about democratic education is expected to increase interaction between students and between students and teachers.

The use of variations in learning methods to avoid boredom in learning when dominated by the lecture method. Use of information an communication technology as a learning resource. He intended to enrich the material delivered to students. The teacher encourages students to be actively involved in learning, not ashamed to express their opinions when learning takes place. School participation in fostering a democratic culture in everyday life, so that democratic education is not only limited to theory, but the theories conveyed can be applied by all school members. Pancasila and Citizenship Education should be able to equip students with adequate intellectual knowledge and skills, making it possible to participate intelligently and responsibly in various dimensions of life in shaping democratic attitudes. With Pancasila and Citizenship Education it is expected to form a more democratic culture of citizenship.

3. Evaluation of democratic education in the learning of Pancasila and Citizenship Education at Surakarta State Senior High School

The way teachers support students has changed. Students are no longer seen as objects in the learning process, but students have been seen as subjects in the learning process. Students are seen as active actors in the learning process. In teacher learning, it is expected to be able to encourage students to develop themselves according to their potential. More teachers function as facilitators, mentors, advisors, motivators of students when learning takes place.

Planning for the implementation of the Pancasila and Citizenship Education learning prepared by teachers by incorporating elements of democratic education, in its implementation is not fully in accordance with the RPP made. Lack of RPP made known when learning takes place. The role of the teacher to present a variety of learning methods when learning takes place, the use of information and communication technology to enrich learning resources is quite maximal. The learning process of Pancasila and Citizenship Education has tended to use the lecture method has begun to be reduced.

\section{CONCLUSION}

Evaluation of the planning of democratic education learning in Pancasila and citizenship education has been designed through the implementation of learning plans. In its implementation, plans for implementing learning are not necessarily as planned. Because it is a plan for implementing learning, in its implementation, there are changes along with the development of the field. The new thing in implementing democracy education through Pancasila education and citizenship has involved the school environment and the community environment to strengthen democratic attitudes and behavior.

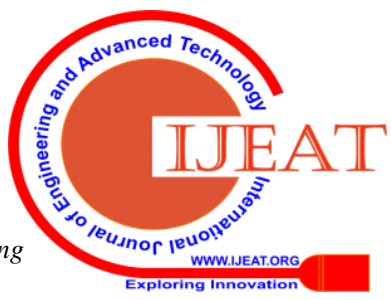




\section{REFERENCES}

[1] Anwar, M.Jafar dan Salam As, M.A. Membumikan Pendidikan Karakter : I Implementasi Pendidikan Berbobot Nilai dan Moral. Jakarta : CV. Suri Tatu'uw. 2015.

[2] Biswatoh Sengupta. Policy issues for e-government services for rural areas International Journal of Electronic Democracy (IJED), Vol. 1, No. 2.. Inderscience Publisher. 2009.

[3] Chatib, Munif. Sekolah Manusia : Sekolah Berbasis Multiple Intelligences di Indonesia. Jakarta : Kaifa. 2009.

[4] Hamdi, Asep S. dan Bahruddin, E. Metode Penelitian Kualitatif dalam Pendidikan. Yogyakarta : Deepublish. 2015.

[5] Kao, Yu-Shu Raissa. Obstacles and Challenges Confronting Principals in the Development of Scholl Democracy Policies in Taiwan. Asian Journal of Management Sciences \& Education, Vol.4, No.2, 2015. pp.52-61.

[6] Lion, Eddy. Pengaruh Pendidikan Kewarganegaraan (PKn) Terhadap Sikap Demokratis Siswa SMA Negeri Se Kota Palngka Raya (Survey Terhadap Siswa Kelas XI SMA Negeri di Kota Palangka Raya). Jurnal Online Pendidikan Ilmu Pengetahuan Sosial, Volume 2, Nomor 2 , (2014).pp. $106-122$.

[7] Luddin, Abu Bakar M. Dasar-Dasar Konseling; Tinjauan Teori dan Praktik. Bandung : Citaplustaka Media Perintis. 2010.

[8] Moswela, Benard. Democratic Education in the Classroom; An Education Law Perspective. Journal of Education Adminstration and Policy Studies, Vol. 2, No. 4, 2010. pp. 56 - 62.

[9] Sagala, Syaiful. Manajemen Strategik dalam Peningkatan Mutu Pendidikan. Bandung; CV. Alfabeta. 2009.

[10] Subba, Dipty. Democratic Values and Democratic Approach in Teaching: A Perspective. American Journal of Educational Research, Vol.2, No. 12A, 2014. pp.. 37-40.

[11] Supriyadi. Seri Buku Ajar Padepokan Karakter: Demokratis. Semarang : Padepokan Karakter PKn FIS Unes. 2015

[12] Suree Funilkul, Wichian, The sustainable development of an e-democracy system. International Journal of Electronic Democracy (IJED), Vol. 1, No. 2, Inderscience Publisher. 2009.

[13] Trisiana, A. The Development Strategy Of Citizenship Education in Civic Education Using Project Citizen Model in Indonesia. Journal of Psychological and Educational Research (JPER), 23 (2), 2015. pp. 111-124.

[14] Trisiana, A. Analysis Of Character Education Policy In Indonesian School To Improve The Asean Economic Community. Research Journal of Applied Sciences (RJAS), Volume 11 (9), pp. 879-883. 2016.

[15] Tuna Baskoy, The European Union and e-democracy: Interactive Policy-Making (IPM). International Journal of Electronic Democracy (IJED), Vol. 1, No. 2,. Inderscience Publisher. 2009.

\section{Author Profile}

I am Yusuf, Student at Doctoral Program in University of SebelasMaret, and Lecture in University of Slamet Riyadi, Surakarta, Indonesia

I am Sri Yutmini Lecture Doctoral Program in University of SebelasMaret, Surakarta, Indonesia

I am Sutarno Joyo Hadikusumo Lecture Doctoral Program in University of SebelasMaret, Surakarta, Indonesia

I am Asrowi Lecture Doctoral Program in University of SebelasMaret, Surakarta, Indonesia 